Article

\title{
Seasonal Variation and Retention of Ammonium in Small Agricultural Streams in Central Thailand
}

\author{
Anh T. T. Le ${ }^{1,2}$, Tamao Kasahara ${ }^{3, *}$ and Varawoot Vudhivanich ${ }^{4}$ \\ 1 Faculty of Environment and Resource Studies, Mahidol University, Salaya Campus, Nakhon Pathom 73170, \\ Thailand; thituyetanh.le@kuleuven.be \\ 2 Center for Environmental Fluid Dynamics, VNU University of Science, Vietnam National University, \\ 334 Nguyen Trai, Thanh Xuan, Hanoi 100803, Vietnam \\ 3 Laboratory of Ecosystem Management, Division of Forest Sciences, Faculty of Agriculture, \\ Kyushu University, 394 Tsubakuro, Sasaguri, Kasuya, Fukuoka 811-2415, Japan \\ 4 Irrigation Technology Research Laboratory, Department of Irrigation Engineering, Faculty of Engineering, \\ Kasetsart University, Kamphaengsaen Campus, Nakhon Pathom 73140, Thailand; fengvwv@ku.ac.th \\ * Correspondence: tamao.kasahara@forest.kyushu-u.ac.jp; Tel.: +81-92-948-3109
}

Received: 1 June 2018; Accepted: 3 July 2018; Published: 5 July 2018

\begin{abstract}
Elevated nutrient concentrations are of concern in many agricultural streams. This study observed seasonal variation of inorganic nitrogen concentrations in small drainage streams that receive discharge predominantly from three different types of agricultural practices, swine farms, aquaculture, and paddy fields, in the Tha Chin River Basin in central Thailand. The drainage streams had high inorganic nitrogen concentrations, low dissolved oxygen concentrations $\left(<3 \mathrm{mg} \mathrm{L}^{-1}\right)$, and ammonium was the dominant form of inorganic nitrogen. The highest ammonium concentrations were observed in the drainage streams through swine farm areas, exceeding $4 \mathrm{mg} \mathrm{L}^{-1}$ throughout the year. In-stream ammonium retention was examined using pulse co-injections of ammonium and chloride in a drainage stream, and the effects of in-channel vegetation on ammonium retention were evaluated. This study showed that a considerable amount of ammonium was retained with the presence of in-channel vegetation. After vegetation removal, both the hydraulic and ammonium uptake length increased by $>50 \mathrm{~m}$, and the ammonium retention declined by approximately $50 \%$. These results suggest that small agricultural streams experience a high concentration of inorganic nitrogen, similar or even more than larger streams, and that in-channel vegetation plays important role in nitrogen retention. The management of in-channel vegetation will have considerable effects on nitrogen transport.
\end{abstract}

Keywords: ammonium retention; agricultural streams; tracer injection; tropical streams

\section{Introduction}

Water quality degradation due to the increase in nutrient loading from agricultural fields are still common in many parts of the world [1,2]. The elevated nutrient concentrations, especially in the form of phosphates, nitrate, and ammonium, caused by discharge from domestic, industry, agriculture, and aquaculture, as well as atmospheric deposition, lead to eutrophication. One of the most obvious signs of eutrophication is the blooming growth of algae and aquatic weed, which induces the depletion of dissolved oxygen and toxicity generation. Eutrophication leads to many adverse effects on biotic organism as well as the utilization of water for human activities such as fishery, recreation, industry, agriculture, and domestic consumption [1,3-7].

Water quality monitoring is taking place in many regions; however, it is often limited to the main stems or large streams. In the agricultural region, numerous small canals are present, and agricultural 
discharges are often dumped directly into those smaller waterways. In the meanwhile, small streams and canals are used for fishing, in-channel farming, swimming, and other domestic purposes by many riverside residents. Thus, the monitoring and improvement of water quality are urgent for the small waterways too.

The Tha Chin River is one of the most eutrophic rivers in Thailand [8], and is a branch of the Chao Phraya River that forms the fourth largest delta in Southeast Asia. Higher nutrient concentrations have led to low dissolved oxygen levels of about $1 \mathrm{mg} \mathrm{L}^{-1}$ in many parts of the Tha Chin River [8]. In small waterways, the growth of dense in-channel vegetation is commonly observed, inhibiting many in-channel activities by the riverside residents. To reduce the unwanted in-channel vegetation, chemical herbicide is sprayed almost annually, which is considered a relatively inexpensive method. Herbicides kill the vegetation, and the vegetation-mat that has died-off is then gradually washed downstream. Because the flows in small streams and canals are controlled by gates and are often of a low velocity, the remains of the plants stay in the canals for weeks after application. An alternative removal method that is used is manual clearing, which is performed once in several years, because of its higher cost. The manual clearing of vegetation results in the instantaneous removal of the vegetation, in contrast to herbicide use, and also smooths the canal bed. To lower the nutrient concentration, mitigation-production approaches, such as in-channel farming, have been proposed [9]. This means a more frequent cycle of the growth of dense vegetation cover and an instantaneous removal of the cover.

Nutrient retention in streams and rivers results from the interaction of biological, chemical, and hydrological processes. In-stream vegetation reduces the nutrient concentration not only through uptake, but also through changes in the hydrodynamic properties [10]. Transient storage is a hydrologic process that affects in-channel nutrient retention and removal, particularly nitrogen, by increasing the residence time and contact of the solutes with biogeochemically active surfaces [11]. These natural abilities to retain and remove nutrients can contribute to the mitigation of excess nutrient loading $[9,12]$. An understanding of the natural capacity in retaining excess nutrients will provide useful information for the development of strategies to achieve water quality improvement with a mitigation-production approach in the network of small canals and streams.

A short-term addition of conservative and reactive tracers has been widely used in the study of nutrient retention [13]. For example, tracer studies have revealed parent lithology through hydraulic conductivity [14], channel morphology [15], background nutrient concentration [16], in-channel vegetation [10], and ecosystem metabolism [17], which influence in-stream nutrient retention.

The present study was carried out in lowland agricultural streams in tropical regions. The objectives were (1) to monitor the seasonal variation in dissolved inorganic nitrogen concentrations in small drainage streams flowing through three common types of agricultural practices, namely swine farms, aquacultures, and paddy fields; and (2) to examine the potential of ammonium retention for small drainage streams and the effects of in-channel vegetation. Agricultural fields are often considered as a non-point source of nutrients, but the direct input of untreated drainage from, for example, paddy fields, swine farms, and aquaculture ponds, may also be considered as point sources. The tracer injection will provide the opportunity to examine the hydraulic and ammonium retention potential of small drainage streams that receives point source input of drainage with a highly elevated nutrient concentration.

\section{Materials and Methods}

\subsection{Study Area Description}

The study was performed in the Tha Chin River Basin located in the Central Plains of Thailand. The study area was located in the province of Nakhon Pathom, which is the middle part of the Tha Chin River (Figure 1), and is known for its intensive agriculture, livestock farming, and aquaculture activities [18]. To accommodate these agricultural activities, dense networks of waterways, including 
natural streams and constructed canals, are present. The water in these streams generally has low concentrations of dissolved oxygen, high concentrations of organic matter, and nutrient levels that exceed the national water quality standards [19].

In the Central Plains of Thailand, the climate is dominated by a monsoon regime with two seasons, a dry season from November to April and a rainy season from May to October. In the period between 2005 and 2010, the Kamphaeng Saen weather station, maintained by the Thai Meteorological Department in Nakhon Pathom province, recorded an average annual rainfall of $1075 \mathrm{~mm}$, more than $80 \%$ of which fell during the rainy season. The average monthly temperature ranged from 25 to $30^{\circ} \mathrm{C}$. The highest and lowest monthly temperatures were $30.6^{\circ} \mathrm{C}$ and $24.8^{\circ} \mathrm{C}$, and occurred in April and December, respectively.

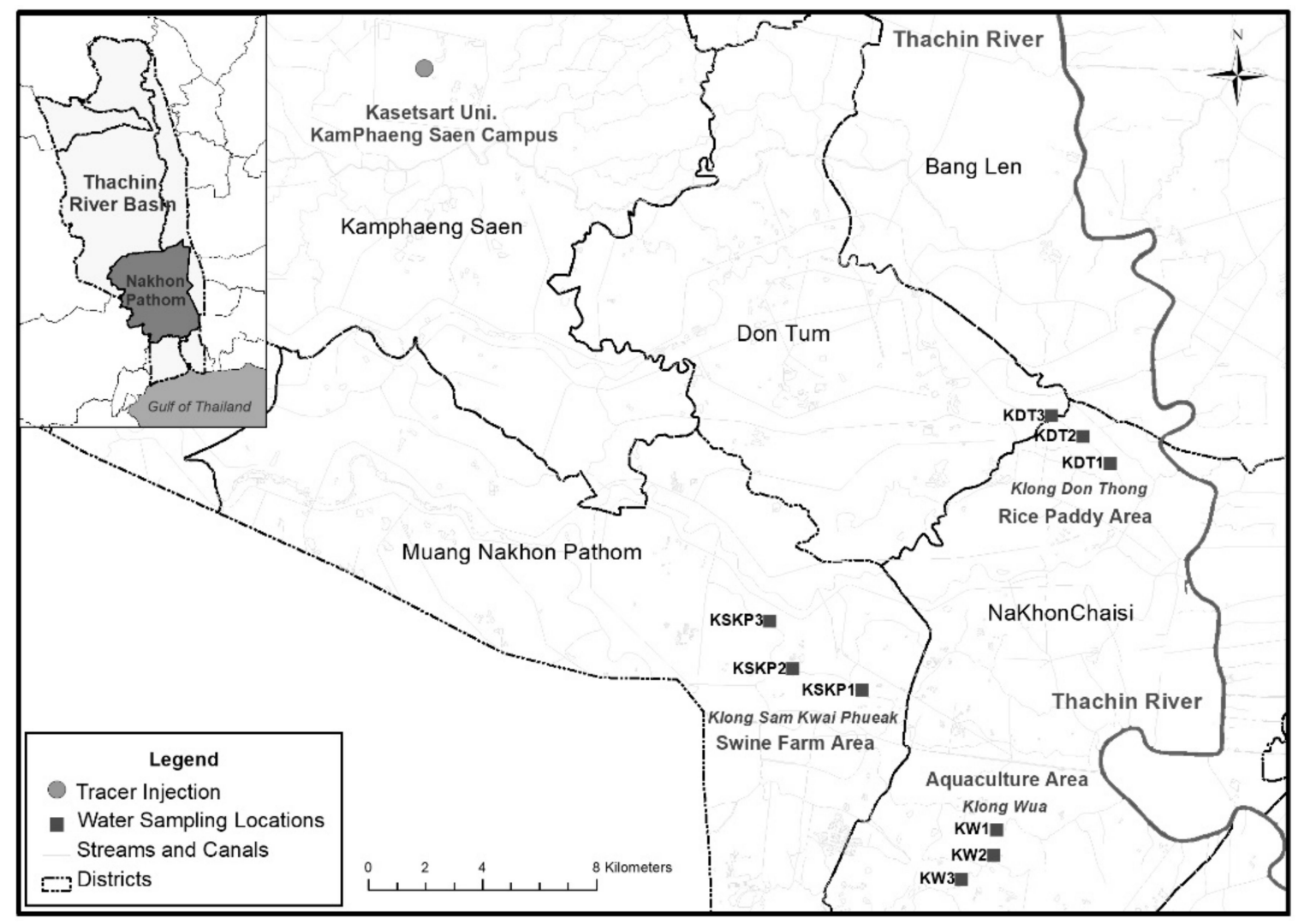

Figure 1. Locations of the water sampling and tracer study streams.

\subsection{Seasonal Variations in Inorganic Nitrogen Concentration}

Water sampling was performed to monitor the concentrations of inorganic nitrogen in small drainage streams flowing through aquaculture, rice paddy, and swine farm areas in the province of Nakhon Pathom. The farms in the area are generally small-scale operations, and each type of production exists in clusters, resulting in, for example, a stream draining through over 30 swine farms in just a few kilometers reach [20]. Small streams and canals collect wastewater from farms, factories, and households and drain into the Tha Chin River. These drainage streams are also used for in-channel farming and domestic water needs. For each type of agricultural practice, a small stream receiving effluent directly from the practice was selected (Figure 1). In each stream or canal, three sampling points, $>3 \mathrm{~km}$ apart from the other points, were selected. Water sampling was performed in January, April, June, August, September, and December in 2010, in order to observe the seasonal variations.

The water samples were transported back to the laboratory on ice and filtered within $24 \mathrm{~h}$ of sampling. The samples were preserved by adding $0.5 \mathrm{~mL} \mathrm{H}_{2} \mathrm{SO}_{4}$ per $500 \mathrm{~mL}$ to obtain a $\mathrm{pH}<2$, and were kept in a refrigerator at $4{ }^{\circ} \mathrm{C}$ prior to analysis. The concentrations of $\mathrm{Cl}, \mathrm{NO}_{3}-\mathrm{N}$, and $\mathrm{NH}_{4}-\mathrm{N}$ were analyzed 
according to the Standard Methods for the Examination of Water and Wastewater using the Argentometric, Nesslerization, and Brucine methods, respectively. At each location, the temperature, dissolved oxygen concentration, specific conductance, and pH were measured using handheld sensors (Horiba ES-51, Kyoto, Japan; and YSI 85, Yellow Springs, OH, USA).

\subsection{Tracer Injection Experiment}

The reach selected for the tracer injection was a small drainage stream flowing through agricultural fields operated by the Kasetsart University-Kamphangsaen campus. The study reach was $210 \mathrm{~m}$ long and was surrounded by irrigated hay and sugar cane fields, and located at $14^{\circ} 1^{\prime} 1^{\prime \prime} \mathrm{N}$ and $99^{\circ} 58^{\prime} 10^{\prime \prime}$ E. The tracer injections were conducted in a straight $210 \mathrm{~m}$ reach, with a channel bed gradient of $0.2 \%$ and a silty substrate. Prior to the study, the canal had not been cleaned or excavated for $>1$ year, and emergent and floating plants were present in the channel. Because of the effects of vegetation, the shape of the channel cross-section varied along the study reach, with an average width of $1.98 \mathrm{~m}$ and depth of $0.10 \mathrm{~m}$ (Table 1 ).

Table 1. Channel characteristics measured in the study reach. CS-cross-section; K-saturated hydraulic conductivity; Width—wetted channel width of the cross-section; Depth—average water depth of the cross-section.

\begin{tabular}{ccccccc}
\hline Caption & $\begin{array}{c}\text { Distance } \\
(\mathbf{m})\end{array}$ & $\begin{array}{c}\boldsymbol{K} \\
\left(\mathbf{c m ~ s}^{-\mathbf{1}} \mathbf{)}\right.\end{array}$ & $\begin{array}{c}\text { Width } \\
(\mathbf{m})\end{array}$ & $\begin{array}{c}\text { Depth } \\
(\mathbf{c m})\end{array}$ & $\begin{array}{c}\text { Width } \\
(\mathbf{m})\end{array}$ & $\begin{array}{c}\text { Depth } \\
(\mathbf{c m})\end{array}$ \\
\hline & & & \multicolumn{2}{c}{ Before removal } & \multicolumn{2}{c}{ After removal } \\
CS1 & 10 & $1.7 \times 10^{-3}$ & 2.10 & 9.4 & 1.90 & 13.0 \\
CS2 & 35 & $1.1 \times 10^{-4}$ & 2.80 & 4.7 & 2.60 & 9.2 \\
CS3 & 80 & $9.6 \times 10^{-5}$ & 1.80 & 8.2 & 1.40 & 12.2 \\
CS4 & 102 & - & 1.50 & 12.1 & 1.20 & 18.4 \\
- & 145 & $3.7 \times 10^{-6}$ & - & - & - & - \\
CS5 & 160 & - & 1.80 & 14.5 & 1.80 & 18.6 \\
CS6 & 210 & $8.6 \times 10^{-6}$ & 1.90 & 11.8 & 1.60 & 19.0 \\
Average & & - & 1.98 & 10.1 & 1.75 & 15.1 \\
\hline
\end{tabular}

The co-injection of chloride and ammonium tracers was carried out in the drainage stream with two purposes, to evaluate retention of ammonium and to assess the change in ammonium retention after the removal of in-channel vegetation. Nitrate is commonly reported as the dominant form of inorganic nitrogen in streams; however, in the present study area, ammonium was consistently the dominant form of inorganic nitrogen, and the nitrate concentrations were $<0.1 \mathrm{mg} \mathrm{L}^{-1}[18,20]$. Therefore, in this study, ammonium was used as the reactive tracer for injection. The first injection was conducted on 2 November 2010 in the canal with emergent and floating vegetation in the channel. On 15 November 2010, the study reach was cleaned to remove all of the in-channel vegetation and to smooth the bed, which is a common practice performed every few years in small streams with dense vegetation cover. In the smoothed stream without vegetation, two tracer injections with different discharges were conducted on 17 November and 9 December 2010. For the studies evaluating nitrogen retention, it is recommended to maintain ambient nutrient concentrations during the tracer addition experiments because the in-stream nutrient retention depends on the nutrient flux and the nutrient limitation status of each stream [21]. In this study, we added nitrogen to increase the concentration so as to examine the reduction of the nitrogen concentration from a point source loading in a small lowland tropical stream, because those streams often receive nitrogen rich agricultural drainage from a pipe directly.

Firstly, the study canal was characterized by surveying six cross-sections (CS) along the study reach; the stream bed and water depth at $10 \mathrm{~cm}$ intervals were measured across the channel, and the extent of the vegetation cover was also recorded. The cross-sections were surveyed before each tracer injection. Piezometer nests (PN) were installed at five of the cross-sections to estimate the saturated 
hydraulic conductivity of the substrate and to collect the groundwater samples. Each location had one-two piezometers installed at different depths $(5,10$, or $20 \mathrm{~cm})$. The piezometers were made from PVC pipes with an inside diameter of $2 \mathrm{~cm}$, which were 'screened' by drilling $0.5 \mathrm{~cm}$ diameter holes for the first $10 \mathrm{~cm}$ from the bottom. The piezometers were installed by hand into the silty bed.

The saturated hydraulic conductivity $(K)$ was measured using a bail-down slug test and the Hvorslev method (see Equation (1)) [20]. The Hvorslev method was used in the present study because the radius of the well screen was shorter than its length, and the entire screen was below the water table [22]. Slug tests were conducted only at the piezometers installed at deeper depths.

$$
K=\frac{r^{2} \ln \left(L_{e} / R\right)}{2 L_{e} T_{o}}
$$

where $K$ is the hydraulic conductivity $\left(\mathrm{cm} \mathrm{s}^{-1}\right), r$ is the radius of the well casing $(\mathrm{cm}), R$ is the radius of the well screen $(\mathrm{cm}), L_{e}$ is the length of the well screen $(\mathrm{cm})$, and $T_{o}$ is the time it takes for the water level to rise or fall to $37 \%$ of the initial change (s).

Along the study reach, the temperature, dissolved oxygen concentration, specific conductance, and $\mathrm{pH}$ were measured at $20 \mathrm{~m}$ intervals prior to the tracer injection in order to determine whether any significant subsurface inflows were present. The values of the four parameters were stable along the $210 \mathrm{~m}$ reach, indicating that there were no major subsurface inflows from the adjacent field.

All of the tracer injection experiments were carried out as a pulse injection of a concentrated solution of the tracers. The quantities of the tracers for injection were determined based on the discharge. The intent was to increase the ammonium concentration at the upstream boundary, close to the highest ammonium concentration observed in the studied agricultural streams. To check whether the experiments were designed adequately for transient storage detection, Damköhler numbers (DaI) was calculated for each experiment [23].

Before and during the injection study, stream water was sampled by hand 10 and $210 \mathrm{~m}$ downstream from the injection point at 5 to 40 s intervals, in order to define the chloride and ammonium concentration breakthrough curves for the upstream and downstream boundaries. In addition to water sampling, the specific conductance (SC) was measured at 10 to $20 \mathrm{~s}$ intervals using handheld sensors (Horiba ES-51, Japan; and YSI 85, USA) at upstream and downstream locations, respectively. Using the relationship between the chloride concentration and the specific conductance developed for the study canal prior to each injection, the specific conductance was used as a surrogate for the chloride concentration to improve the chloride breakthrough curve. The SC breakthrough curve at the upstream site was also used to estimate the canal discharge by applying the salt dilution gauging method [24].

\subsection{Estimation of the Hydraulic and Nutrient Retention}

To evaluate the hydraulic retention, the One-Dimensional Transport with Inflow and Storage with Parameter optimization model (OTIS-P, http:/ / co.water.usgs.gov/ otis) [25] was used, which has been used extensively in streams $[14,15,26]$, and was used in this study to estimate the transient storage parameters from the chloride breakthrough curve. The parameter estimation for the OTIS-P model was used to determine an optimal set of parameters that best fit the observed data. The parameters estimated by OTIS-P, such as the exchange coefficient $(\alpha)$, storage zone cross-section area $(A s)$, and stream cross-section area $(A)$, were then used to calculate the relative transient storage size $(A s / A)$, the hydraulic residence times (hours), hydraulic uptake length $\left(S_{\text {hyd }}\right)(\mathrm{m})$, and hydrologic retention factor $R_{h}\left(\mathrm{~s} \mathrm{~m}^{-1}\right)$ [26]. The hydraulic residence times in the stream $\left(T_{\text {str }}\right)$ and in storage $\left(T_{\text {sto }}\right)$ were defined using the following equations:

$$
\begin{gathered}
T_{\text {str }}=1 / \alpha \\
T_{\text {sto }}=A s /(A \alpha)
\end{gathered}
$$


The hydraulic uptake length is the average distance of solute downstream transport, prior to entry of the solute into the storage zone.

$$
S_{\text {hyd }}=Q /(A \alpha)
$$

The hydrologic retention factor for solutes is the storage zone residence time of the conservative tracer, per unit of downstream transport.

$$
R_{h}=T_{\text {sto }} / S_{\text {hyd }}
$$

To evaluate the nutrient retention potential of the study reach, uptake metrics, such as uptake length $\left(S_{w}\right)$, uptake velocity $\left(V_{f}\right)$, and uptake rate $(U)$, were also calculated from the chloride and ammonium breakthrough curves $[27,28] . S_{w}(\mathrm{~m})$ was calculated as $v / k_{t}$, where $\mathrm{v}$ is the average water velocity and $k_{t}$ is the temporal uptake rate coefficient $\left(k_{t}\right)$. The mass balance between the injected tracer $\left(M_{i}\right)$ and the recovered tracer at the downstream sampling location $\left(M_{r}\right)$ were used to estimate $k_{t}$.

$$
k_{t}=\frac{\ln \left(\frac{M_{i}}{M_{r}}\right)}{t_{p}}
$$

where $t_{p}$ is the time taken for the concentration centroid to arrive at the downstream sampling location. $V_{f}\left(\mathrm{~m} \mathrm{~h}^{-1}\right)$ was calculated using $S_{w}, v$, and $z$ (average depth), as follows:

$$
V_{f}=\frac{v z}{S_{w}}
$$

The areal nutrient uptake rate $\left(\mathrm{mg} \mathrm{m}^{-2} \mathrm{~h}^{-1}\right)$ was calculated using the following equation:

$$
U=\frac{Q C}{S_{w} w}
$$

Ammonium retention was also evaluated using the differences between the observed and predicted ammonium concentrations at each sampling location [29]. The predicted concentration is the expected concentration if there were no biological and chemical processes to retain ammonium. Without those retention processes, the ratio of chloride to ammonium is assumed to remain constant. a lower observed ammonium concentration than the predicted value indicates the presence of retention processes.

\section{Results and Discussion}

\subsection{Seasonal Variation in Nitrogen Concentration in the Small Agricultural Streams}

The flow was measured for every sampling, except in January (Figure 2). The canal through the swine farm area was the largest, with a flow twice that of the aquaculture and rice paddy areas. Although no measurement of flow was performed in January, the dry season began in November and continued until April; therefore, the flow was expected to be small in January.

The nitrate concentration was consistently $\leq 0.1 \mathrm{mg} \mathrm{L}^{-1} \mathrm{NO}_{3}-\mathrm{N}$ at all of the sampling locations and all of the sampling times, and the ammonium concentration was higher; therefore, the results here focused on the ammonium concentration. The stream in the swine farm area exhibited consistently higher ammonium concentrations and larger seasonal variations compared with the streams flowing through the rice paddy and aquaculture pond areas (Figure 2), and the concentration was highest in January during the dry period, reaching $>30 \mathrm{mg} \mathrm{L}^{-1} \mathrm{NH}_{4}-\mathrm{N}$. The streams through the aquaculture pond and rice paddy areas also exhibited a similar trend, with the concentration increasing in the dry period, however, the seasonal fluctuations in these streams was much smaller; the highest concentrations were $3.9 \mathrm{mg} \mathrm{L}^{-1}$ and $2.3 \mathrm{mg} \mathrm{L}^{-1}$ in the aquaculture pond and rice paddy areas, respectively. 


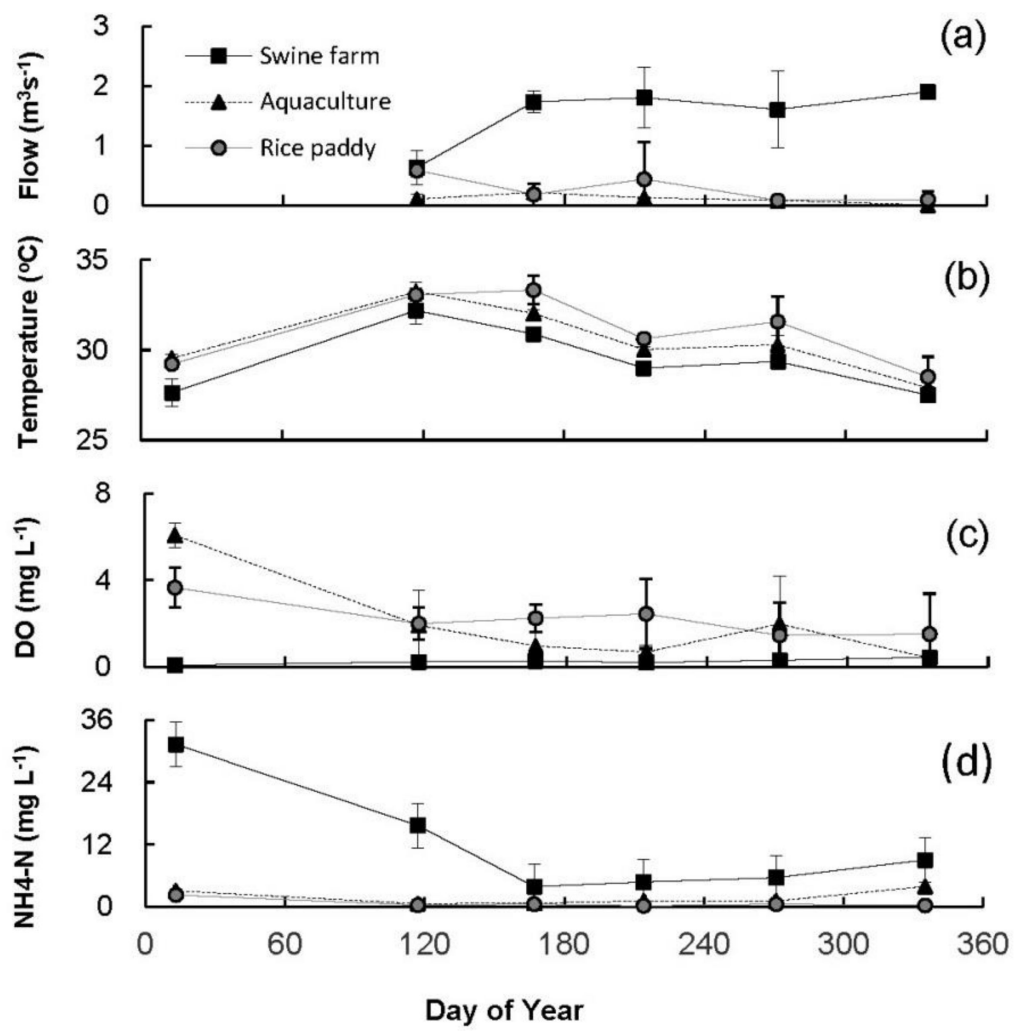

Figure 2. Seasonal changes in flow (a), temperature (b), dissolved oxygen (DO) (c), and $\mathrm{NH}_{4}-\mathrm{N}(\mathbf{d})$ in the study streams and canals. The values are the average of the three sampling points in each stream. The data from the swine farms are shown in square, rice paddies in circle, and aquaculture ponds in triangle.

The dissolved oxygen (DO) concentrations in the streams were low, particularly in the swine farm area, with a concentration of $<1 \mathrm{mg} \mathrm{L}^{-1}$ throughout the study year. The drainage streams through the aquaculture pond and rice paddy areas had higher concentrations, but were $<3 \mathrm{mg} \mathrm{L}^{-1}$ most of the year. This low DO may contribute to the high ammonium concentrations. The drainage pipe from the swine farm discharges water with very high concentrations of ammonium directly to the stream. Nitrate often shows higher concentrations than ammonium in stream water [30,31], and the reason that ammonium stayed as the dominant form of inorganic nitrogen in the studied drainage stream in all of the seasons may be, in part, due to low DO concentration of the water.

The concentrations of ammonium were high at all three of the drainage streams studied, especially in the dry season when the flow and temperature were low. The larger volume of flow may have lowered the concentration because of dilution, thus resulting in lower ammonium concentrations in the high flow season, and higher concentration in the low flow season. When three types of agricultural practices were compared, the stream with largest flow, through the swine farm areas, had a significantly higher ammonium concentration than the streams through the aquaculture and rice paddy field area. The concentrations observed in the stream through the swine farm area were higher than the previous studies in the agricultural streams [30-32]. These results suggest that the input of ammonium from the swine farm is much greater than the ones from the aquaculture and rice paddy field area. a previous study reported that the outflow from the swine farm has higher ammonium concentrations, even compared to other types of livestock [33]. The presence of a relatively high density of small-scale swine farms with direct discharge of waste water might have resulted in low DO and high ammonium concentrations. Despite the difference in the ammonium concentrations, all three of the drainage streams had high ammonium concentrations and resulted in dense patches of in-channel vegetation in several locations, with some patches extended $>50 \mathrm{~m}$ in the stream length. Therefore, it was in need to evaluate the potential of the in-stream nitrogen retention and the effects of in-channel vegetation. 


\subsection{In-Stream Hydraulic and Nitrogen Retention}

In the upstream portion of the study reach (CS1-2), the stream was wide and shallow, and emergent vegetation was present on both sides (Figure 3, Table 1). The average width in the upstream reach was larger than that in the middle and downstream $(2.45,1.65$, and $1.85 \mathrm{~m}$, respectively). The middle of the stream reach (CS3-4) had relatively dense vegetation on both banks, with some also present across the active channel (Figure 3 and Table 1). The downstream portion of the study channel (CS5-6) had less in-channel vegetation with narrower and deeper cross-sections (Figure 3 and Table 1). The saturated hydraulic conductivity of the substrate decreased along the $210 \mathrm{~m}$ stretch of the study canal. At $10 \mathrm{~m}$ from the injection point, the value of $K$ was relatively high at $1.7 \times 10^{-3} \mathrm{~cm} \mathrm{~s}^{-1}$, but quickly decreased to $<9.0 \times 10^{-6} \mathrm{~cm} \mathrm{~s}^{-1}$ in the downstream half of the study reach (Table 1 ).

(a) Upstream reach (CS2)
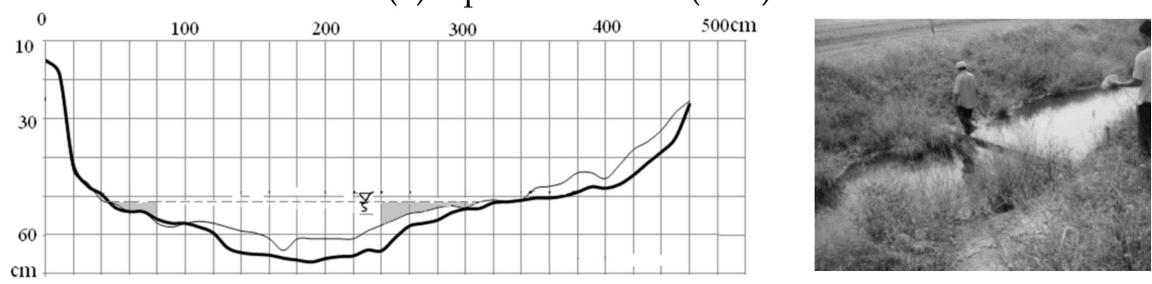

(b) Middle reach (CS3)
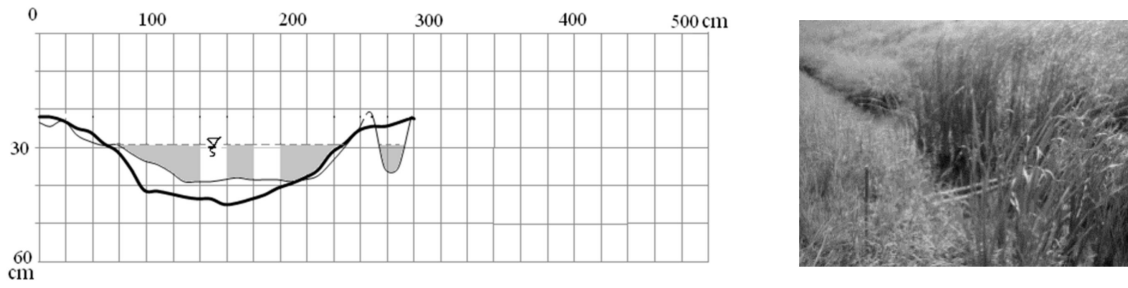

(c) Downstream reach (CS6)
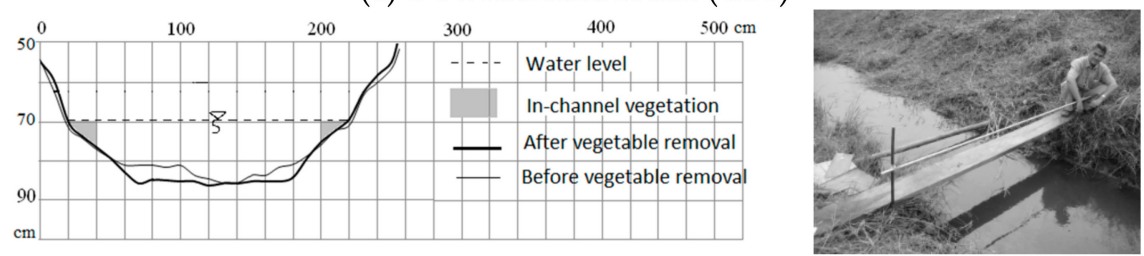

Figure 3. Changes in cross-section before and after vegetation removal in the study reach of the tracer injection experiment. (a) Upstream reach, (b) middle reach, and (c) downstream reach. The gray shaded area indicates the presence of vegetation, and all of the photos were taken on 2 November 2010, before vegetation removal.

The DaI were 1.1 to 3.9 for the three experiments (Table 2), indicating that the studied reach lengths were adequate to detect transient storage. With the presence of vegetation, the tracer injection study was carried out on 2 November 2010, and the OTIS-P simulations were fitted to the chloride breakthrough curve on the basis of the linear regression of the predicted versus observed data, to estimate the hydrologic parameters (Figure 4 and Table 2). a root mean square error (RMSE) of 6.32 and a $\mathrm{R}^{2}$ of 0.82 were obtained. The OTIS-P-derived relative size of transient storage zone $(A s / A)$ of 0.39 , and the hydraulic uptake length $\left(S_{h y d}\right)$ and retention factor $\left(R_{h}\right)$ were estimated to be $198 \mathrm{~m}$ and $5.75 \mathrm{~s} \mathrm{~m}^{-1}$, respectively (Table 2). The ammonium retention parameters, the uptake length $\left(S_{w}\right)$, uptake velocity $\left(V_{f}\right)$, and uptake rate $(U)$, estimated for the study reach with vegetation were $505 \mathrm{~m}$, $0.05 \mathrm{~mm} \mathrm{~h}^{-1}, 0.08 \mathrm{mg} \mathrm{m}^{-2} \mathrm{~h}^{-1}$, respectively. The observed ammonium concentration was consistently lower than the predicted value, suggesting the presence of ammonium retention (Figure 5). In addition, although the difference in the ammonium concentrations between the upstream and downstream measurement points became larger as the concentration of injected ammonium increased, the reduction 
of the concentration within the study reach was quickly stabilized (Figure 5a) at around the decline of $10.2 \mathrm{mg} \mathrm{L}^{-1}$ (Table 3).

Table 2. Parameters relating to hydraulic and nitrogen retention calculated from chloride and ammonium breakthrough curves (BTCs) of three experiments with vegetation conducted on 2 November 2010 and without vegetation conducted on 17 November and 9 December 2010.

\begin{tabular}{|c|c|c|c|c|}
\hline \multirow{2}{*}{ Caption } & & \multirow{2}{*}{$\begin{array}{c}\text { With Vegetation } \\
2 \text { November }\end{array}$} & \multicolumn{2}{|c|}{ Without Vegetation } \\
\hline & & & 17 November & 9 December \\
\hline Discharge & $Q\left(\mathrm{~L} \mathrm{~s}^{-1}\right)$ & 12 & 18 & 30 \\
\hline Damköhler number & $\mathrm{DaI}$ & 1.1 & 1.8 & 3.9 \\
\hline \multicolumn{5}{|l|}{ Hydraulic retention } \\
\hline Longitudinal dispersion & $D\left(\mathrm{~m}^{2} \mathrm{~s}^{-1}\right)$ & 0.130 & 0.040 & 0.119 \\
\hline Storage exchange coefficient & $\alpha\left(10^{-4} \mathrm{~s}^{-1}\right)$ & 3.40 & 2.50 & 3.00 \\
\hline Relative size of transient storage zone & As/A & 0.39 & 0.16 & 0.07 \\
\hline Stream residence time & $T_{\text {str }}(\mathrm{h})$ & 49.0 & 66.7 & 55.6 \\
\hline Storage zone residence time & $T_{\text {sto }}(\mathrm{h})$ & 19.0 & 10.4 & 4.1 \\
\hline Hydraulic uptake length & $S_{\text {hyd }}(\mathrm{m})$ & 198 & 400 & 504 \\
\hline Retention factor & $R_{h}\left(\mathrm{~s} \mathrm{~m}^{-1}\right)$ & 5.75 & 1.56 & 0.49 \\
\hline \multicolumn{5}{|l|}{ Ammonium retention } \\
\hline Uptake length & $S_{w}(\mathrm{~m})$ & 505 & 558 & 1461 \\
\hline Uptake velocity & $V_{f}\left(\mathrm{~mm} \mathrm{~h}^{-1}\right)$ & 0.05 & 0.12 & 0.06 \\
\hline Uptake rate & $U\left(\mathrm{mg} \mathrm{m}^{-2} \mathrm{~h}^{-1}\right)$ & 0.08 & 0.05 & 0.02 \\
\hline
\end{tabular}

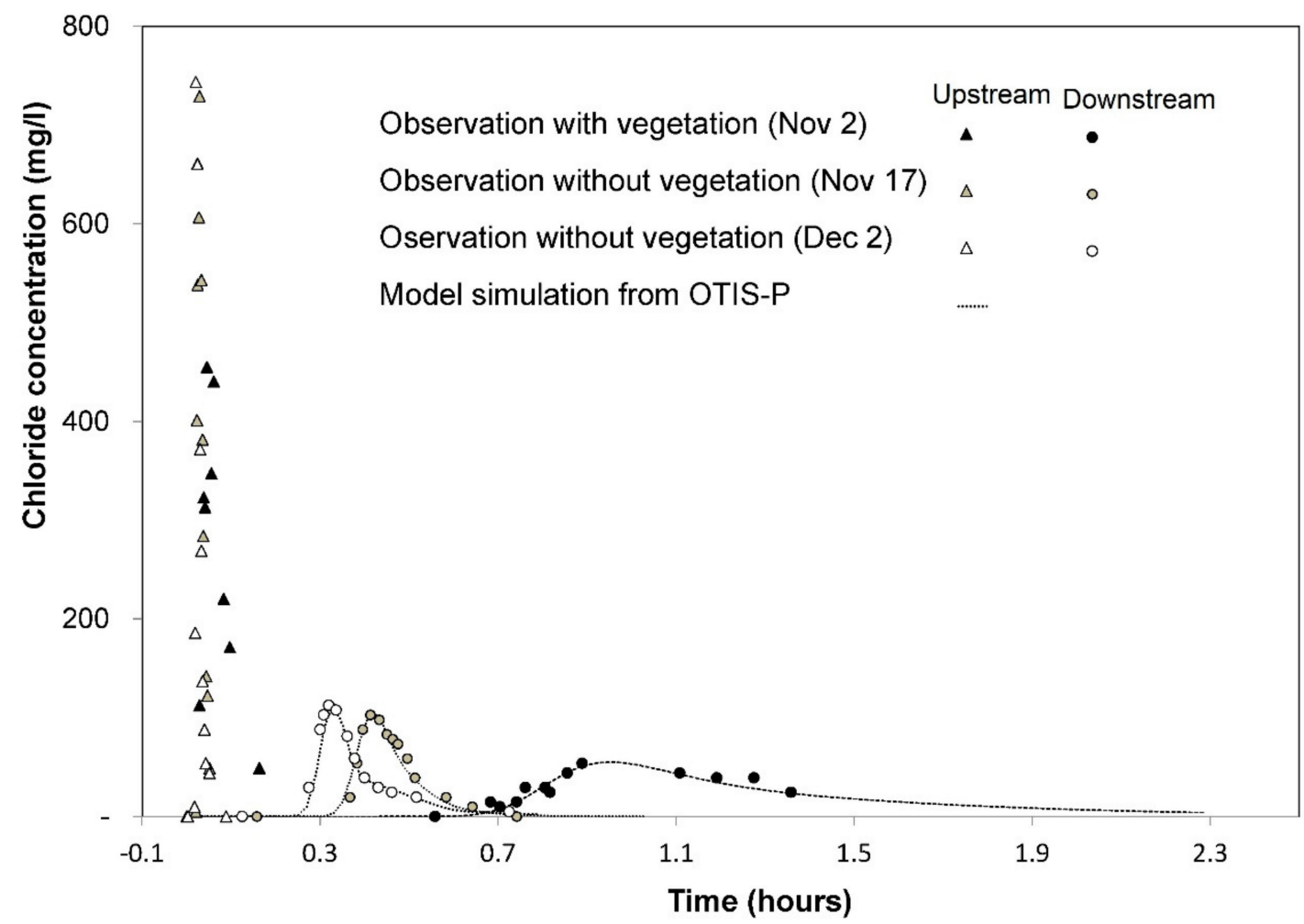

Figure 4. Breakthrough curves of the chloride concentrations from three tracer experiments. Black symbols show the data from tracer injection, on 2 November 2010, with vegetation. Gray and white symbols show the data from 17 November and 9 December 2010, respectively, without vegetation. Triangle symbols show the upstream boundary and the circle shows the downstream boundary. The dashed lines indicate the model simulation from the One-Dimensional Transport with Inflow and Storage with Parameter (OTIS-P). Injection started at time 0. 


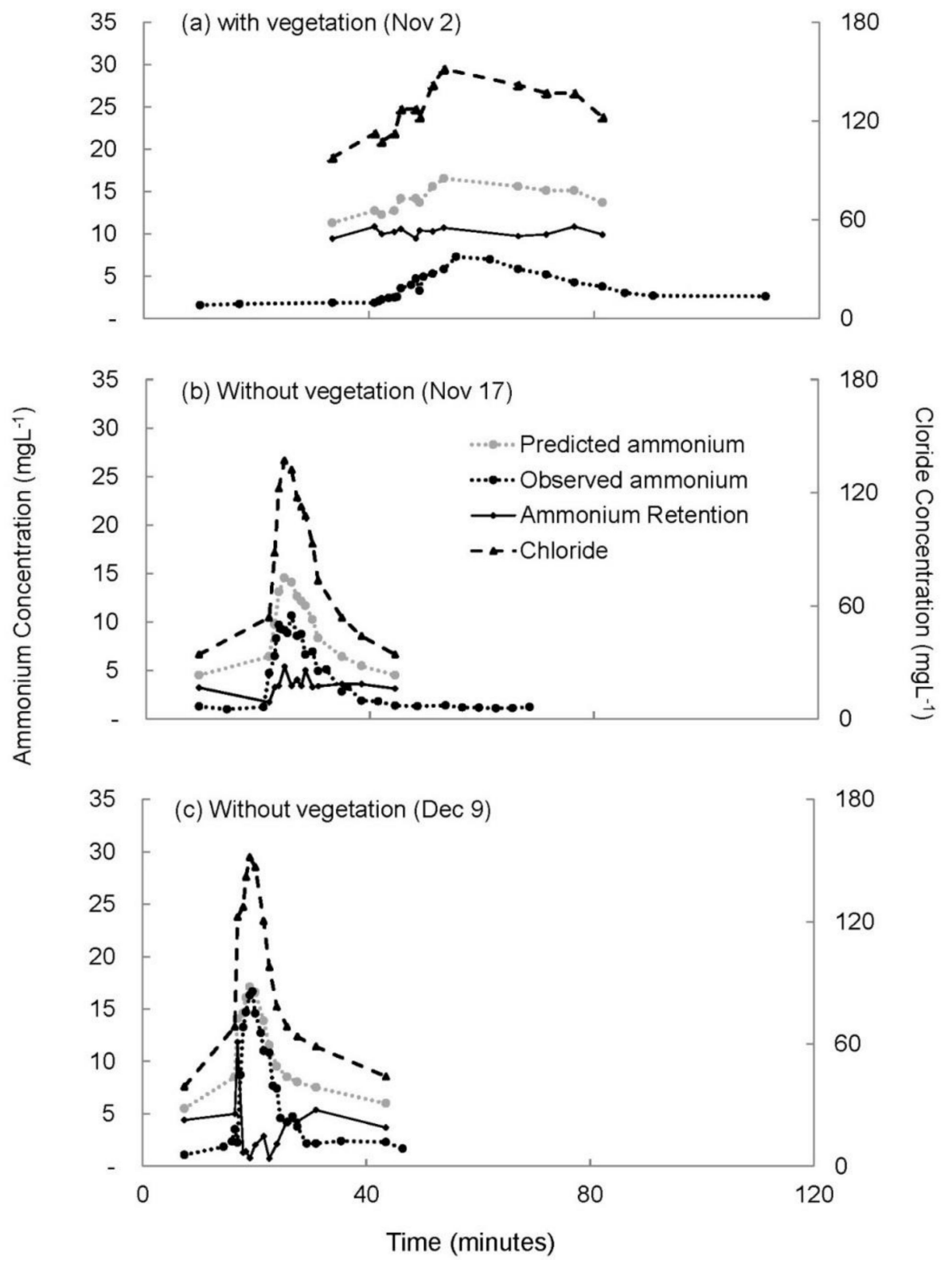

Figure 5. Changes in the concentration of chloride and ammonium at the downstream $(210 \mathrm{~m})$ sampling point during the experiment on 2 November (a), 17 November (b), and 9 December 2010 (c), respectively. The predicted ammonium concentration is the expected concentration of ammonium if there was no retention. Ammonium retention is the difference between the predicted and observed concentrations.

Table 3. Ammonium retention $\left(\mathrm{mg} \mathrm{L}^{-1}\right)$ at downstream reaches of the experiments with vegetation and without vegetation. $n$ is sample size.

\begin{tabular}{ccccccc}
\hline & Date & $\boldsymbol{n}$ & Max & Min & Average & Median \\
\hline With vegetation & 2 November & 13 & 11.02 & 9.45 & 10.22 & 10.23 \\
\hline \multirow{2}{*}{ Without vegetation } & 17 November & 13 & 5.36 & 0.71 & 2.94 & 2.86 \\
& 9 December & 14 & 5.38 & 1.73 & 3.59 & 3.41 \\
\hline
\end{tabular}

The drainage stream used for the injection experiment had channel characteristics similar to those of other agricultural streams in the region. The drainage streams generally have a low channel gradient, a simple channel geometry, and a fine-grain substrate. In addition, a lower flow velocity is 
common because of the control of the flow by the head gates, which, in part, support the expansion of emergent and floating vegetation. These channel characteristics minimize the surface-subsurface water exchange and increase the importance of surface transient storage [10]. Thus, the estimates of the in-stream ammonium retention from the tracer experiments are considered applicable to the drainage streams in the region.

The hydraulic retention decreased after the removal of in-channel vegetation in the study reach. The $A s / A$ decreased by $>50 \%$ when the discharges were similar after the vegetation removal, and the hydraulic uptake length and hydrologic retention without vegetation were approximately 2 times longer and 3.7 times smaller, respectively, than those values the reached with vegetation (Table 3). The solutes were thus more likely to be retained longer in the reach when the vegetation was present. These results agreed well with those of previous studies that revealed the increased transient storage and hydrologic retention with increasing in-channel vegetation [34]. Dense aquatic plants and algae increase the surface transient storage, which enhances uptake and contact between the solutes and the biogeochemical reactive substrate, and consequently increases the nitrogen retention potential [14,34,35].

The low saturated hydraulic conductivity suggests that the exchange between the surface and subsurface is small [36,37], and thus, the subsurface transient storage is negligible in the study reach. The influence of in-channel vegetation and channel morphology on transient storage and nutrient uptake rates has been reported. Harvey et al. (2003) [37] found that aquatic vegetation created in-channel transient storage, which contributed to flow resistance in an Arizona stream. Salehin et al. (2003) [10] reported a greater surface transient storage in a vegetated reach than in un-vegetated reaches, in part due to the changes in porosity of the streambed sediments caused by the vegetation growth.

The uptake metrics showed that the in-stream ammonium retention declined after the removal of vegetation and with the increase in flow. The higher in-channel transient storage due to the presence of vegetation was reported to increase the ammonium retention [15], thus the decline in hydraulic retention may have resulted in a low ammonium retention after vegetation removal in this study. Ammonium retention occurs because of biotic processes such as nitrification, plant uptake, and microbial immobilization [15], as well as abiotic processes including volatilization and sorption [38]. The nitrate concentration was $\leq 0.1 \mathrm{mg} \mathrm{L}^{-1}$ throughout the experiment, suggesting that nitrification was negligible in the study reach, where the dissolved oxygen concentration was equal to or less than $3 \mathrm{mg} \mathrm{L}{ }^{-1}$. The surface water in the study canal had a $\mathrm{pH}$ of 7.2, which does not support significant volatilization [39]. We increased the ammonium concentration close to $30 \mathrm{mg} \mathrm{L}^{-1}$, higher than the ambient concentration, because similar levels of high concentrations were observed in the dry season in the drainage streams in intensive agricultural areas of the central Tha Chin River Basin (Figure 2). This steep increase in ammonium concentration most likely saturated the uptake rates [15], and the sorption to the sediment may have also accounted for a portion of the ammonium retention [38].

Two tracer injection experiments after the vegetation removal were performed under different flow conditions $\left(18 \mathrm{Ls}^{-1}\right.$ and $\left.30 \mathrm{Ls}^{-1}\right)$. Several studies have examined the effect of the discharge on transient storage. Wondzell (2006) [40] showed that, in the range of the base flow discharge for a mountain stream, the stream discharge had little influence on the exchange fluxes and residence time distributions for the hyporheic exchange flow [31]. Valett et al. (1996) [14] and Morrice et al. (1997) [26] reported, however, that larger discharges resulted in reduced transient storage, longer hydraulic uptake lengths, and lower hydrologic retention values because of the increased velocity. In the present study, the transient storage $(A s / A)$ and hydrologic retention values decreased as the discharge increased, which is in agreement with the results of previous studies. The ammonium uptake metrics also showed a decline in ammonium retention with discharge increase.

Small streams and canals in Central Thailand and agricultural regions of Southeast Asia, in general, suffer from serious water quality problems. Eutrophication is one of the main problems, and even some of the larger rivers are severely impacted [7]. While the reduction of excess nutrient loading should be the primary focus, understanding the capacity of rivers to reduce excessively loaded nutrients and the development of regular waterway management plans will help to improve the water quality. 
In fact, the results of this study suggest that the canals in this tropical region have the potential to reduce a considerable portion of the injected nitrogen. The manual clearing of vegetation, which is necessary for navigation and other water uses, was also shown to quickly reduce the nitrogen retention. The effects of vegetation on the ammonium concentration are likely retention rather than removal; therefore, the cleaning of canals is also an important method for removing nutrients from canal systems. However, the timing of cleaning can be strategically planned. The concentration of nitrogen in canal waters fluctuates seasonally and varies for canals that pass through the land used for different types of agricultural practices [20]. Thus, the cleaning of canals in severely impacted areas, such as swine farm areas, should be performed when the concentration is lowest, so as to minimize the sudden increase of nitrogen transport to downstream reaches.

\section{Conclusions}

The dominant form of inorganic nitrogen in the canals and rivers in Central Thailand was found to be ammonium, while the nitrate concentrations were consistently below the detection limit. The ammonium concentration showed seasonal variation, with high concentrations during dry season with a low flow in the streams. The co-injection of chloride and ammonium showed the presence of in-stream ammonium retention. The uptake metrics showed a relatively low nitrate potential, however, in case a high concentration of ammonium was released as a pulse, a considerable portion of ammonium was retained when in-channel vegetation was presented. After the removal of the vegetation, the ammonium retention declined by approximately $50 \%$. Vegetation removal is important because it removes the retained nitrogen from the stream system and thus plays a role in water quality control. However, based on the results of this study, it is important to note that the timing of canal cleaning should be strategically planned to avoid a sudden increase in nitrogen transport to downstream areas.

Author Contributions: A.T.T.L., T.K., and V.V. designed the projects and conducted field experiments; A.T.T.L. and T.K. analyzed the data and wrote the paper; and V.V. improved the paper.

Funding: This research project was funded by the National Research Council of Thailand.

Acknowledgments: We thank the Faculty of the Environment and Resource Studies at Mahidol University and the Faculty of Engineering at the Kasetsart University (Kamphaengsean campus) for allowing us to use their facilities. We also thank the Thailand International Development Cooperation Agency for their financial support. We greatly appreciate Mr. Rawee and his crew for their help in the fieldwork. Two anonymous reviewers provided valuable comments, which much improved the paper, and we would like to thank them here.

Conflicts of Interest: The authors declare no conflict of interest. The funders had no role in the design of the study; in the collection, analyses, or interpretation of data; in the writing of the manuscript; and in the decision to publish the results.

\section{References}

1. Smith, V.H. Eutrophication of freshwater and coastal marine ecosystems: a global problem. Environ. Sci. Pollut. Res. Int. 2003, 10, 126-139. [CrossRef] [PubMed]

2. Ta, T.T.; Trinh, D.A.; Do, N.T. Nitrogen flow assessment in rapidly urbanizing Hai Duong province, downstream of Cau River Basin, Vietnam. J. Mater. Cycles Waste Manag. 2018, 20, 533-542. [CrossRef]

3. Smith, V.H.; Tilman, G.D.; Nekola, J.C. Eutrophication: Impacts of excess nutrient inputs on freshwater, marine, and terrestrial ecosystems. Environ. Pollut. 1999, 100, 179-196. [CrossRef]

4. Carpenter, S.R.; Caraco, N.F.; Correll, D.L.; Howarth, W.R.; Sharpley, N.A.; Smith, H.V. Nonpoint pollution of surface waters with phosphorus and nitrogen. Ecol. Appl. 1998, 8, 559-568. [CrossRef]

5. Nijboer, R.C.; Verdonschot, P.F.M. Variable selection for modelling effects of eutrophication on stream and river ecosystems. Ecol. Model. 2004, 177, 17-39. [CrossRef]

6. Nyenje, P.M.; Foppen, J.W.; Uhlenbrook, S.; Kulabako, R.; Muwanga, A. Eutrophication and Nutrient Release in Urban Areas of Sub-Saharan Africa-A Review. Sci. Total Environ. 2010, 408, 447-455. [CrossRef] [PubMed] 
7. Hilton, J.; O'Hare, M.; Bowes, M.J.; Jones, J.I. How green is my river? a new paradigm of eutrophication in rivers. Sci. Total Environ. 2006, 365, 66-83. [CrossRef] [PubMed]

8. Meksumpun, C.; Meksumpun, S. Integration of aquatic ecology and biological oceanographic knowledge for development of area-based eutrophication assessment criteria leading to water resource remediation and utilization management: a case study in Tha Chin, the most eutrophic river of Thailand. Water Sci. Technol. 2008, 58, 2303-2311. [PubMed]

9. Mahujchariyawong, J.; Ikeda, S. Modelling of environmental phytoremediation in eutrophic river-The case of water hyacinth harvest in Tha-chin River, Thailand. Ecol. Model. 2001, 142, 121-134. [CrossRef]

10. Salehin, M.; Packman, A.I.; Worman, A. Comparison of transient storage in vegetated and unvegetated reaches of a small agricultural stream in Sweden: Seasonal variation and anthropogenic manipulation. Adv. Water Resour. 2003, 26, 951-964. [CrossRef]

11. Gooseff, M.N.; LaNier, J.; Haggerty, R.; Kokkeler, K. Determining in-channel (dead zone) transient storage by comparing solute transport in a bedrock channel-alluvial channel sequence, Oregon. Water Resour. Res. 2005, 41. [CrossRef]

12. Lawrence, J.E.; Skold, M.E.; Hussain, F.A.; Silverman, D.R.; Resh, V.H.; Sedlak, D.L.; Luthy, R.G.; McCray, J.E. Hyporheic Zone in Urban Streams: a Review and Opportunities for Enhancing Water Quality and Improving Aquatic Habitat by Active Management. Environ. Eng. Sci. 2013, 30, 480-501. [CrossRef]

13. Stream, S.W. Concepts and methods for assessing solute dynamics in stream ecosystems. J. N. Am. Benthol. Soc. 1990, 9, 95-119.

14. Valett, H.M.; Morrice, J.A.; Dahm, C.N.; Campana, M.E. Parent lithology, surface-groundwater exchange, and nitrate retention in headwater streams. Limnol. Oceanogr. 1996, 41, 333-345. [CrossRef]

15. Gücker, B.; Boëchat, I.G. Stream Morphology Controls Ammonium Retention in Tropical Headwaters. Ecology 2004, 85, 2818-2827. [CrossRef]

16. Dodds, W.K.; Jones, J.R.; Welch, E.B. Suggested classification of stream trophic state: Distributions of temperate stream types by chlorophyll, total nitrogen, and phosphorus. Water Res. 1998, 32, 1455-1462. [CrossRef]

17. Hall, R.O.J.; Tank, J.L. Ecosystem metabolism controls nitrogen uptake in streams in Grand Teton National Park, Wyoming. Limnol. Oceanogr. 2003, 48, 1120-1128. [CrossRef]

18. Schaffner, M.; Bader, H.; Scheidegger, R. Modeling the contribution of point sources and non-point sources to Thachin River water pollution. Sci. Total Environ. 2009, 407, 4902-4915. [CrossRef] [PubMed]

19. Schaffner, M.; Wittmer, I. The Thachin River is overloaded with nutrients. Eawag 2007, 62, 18-20.

20. Le, T.T.A. Estimation of In-Channel Nitrogen Retention in a Small Tropical Stream Using One-Dimensional Transport with Inflow and Storage (OTIS) Model. Master's Thesis, Mahidol University, Chang Wat Nakhon Pathom, Thailand, 2011.

21. Mulholland, P.J.; Tank, J.L.; Webster, J.R.; Bowden, W.B.; Dodds, W.K.; Gregory, S.V.; Grimm, N.B.; Hamilton, S.K.; Johnson, S.L.; Martí, E.; et al. Can uptake length in streams be determined by nutrient addition experiments? Results from an interbiome comparison study. J. N. Am. Benthol. Soc. 2002, 21, 544-560. [CrossRef]

22. Fetter, C.W. Applied Hydrogeology, 3rd ed.; Prentice-Hall, Inc.: Upper Saddle River, NJ, USA, $1994 ;$ p. 691.

23. Harvey, J.W.; Wagner, B.J. Quantifying hydrologic interactions between streams and their subsurface hyporheic zones. In Streams and Ground Waters; Jones, J.B., Mulholland, P.J., Eds.; Academic Press: San Diego, CA, USA, 2000.

24. Moore, R.D. Slug Injection Using Salt in Solution. Stream Water Manag. Bull. 2005, 8, 1-6.

25. Runkel, R.L.; McKnight, D.M.; Andrews, E.D. Analysis of transient storage subject to unsteady flow: Diel flow variation in an Antarctic stream. J. N. Am. Benthol. Soc. 1998, 17, 145-154. [CrossRef]

26. Morrice, J.A.; Valett, H.M.; Dahm, C.N.; Champana, M.E. Alluvial characteristics, groundwater-surface water exchange and hydrological retention in headwater streams. Hydrol. Process. 1997, 11, 253-267. [CrossRef]

27. Covino, T.P.; McGlynn, B.L.; McNamara, R.A. Tracer Additions for Spiraling Curve Characterization (TASCC): Quantifying stream nutrient uptake kinetics from ambient to saturation. Limnol. Oceanogr. Methods 2010, 8, 484-498. [CrossRef]

28. García, V.J.; Gantes, P.; Giménez, L.; Hegoburu, C.; Ferreiro, N.; Sabater, F.; Feijoó, C. High nutrient retention in chronically nutrient-rich lowland streams. Freshw. Sci. 2017, 36, 26-40. [CrossRef] 
29. Kasahara, T.; Hill, A.R. Lateral Hyporheic Zone Chemistry in an Artificially Constructed Gravel Bar and a Re-Meandered Stream Channel, Southern Ontario, Canada. J. Am. Water Resour. Assoc. 2007, 43, 1257-1269. [CrossRef]

30. Johnson, L.B.; Richards, C.; Host, G.E.; Authur, J.W. Landscape influences on water chemistry in Midwestern stream ecosystems. Freshw. Biol. 1997, 37, 193-208. [CrossRef]

31. Goolsby, D.A.; Battaglin, W.A.; Aulenbach, B.T.; Hooper, R.P. Nitrogen flux and sources in the Mississippi River Basin. Sci. Total Environ. 2000, 248, 75-86. [CrossRef]

32. Collins, R.; Jenkins, A. The impact of agricultural land use on stream chemistry in the Middle Hills of the Himalayas, Nepal. J. Hydrol. 1996, 185, 71-86. [CrossRef]

33. Knight, R.L.; Payne, V.W.E.; Borer, R.E.; Clarke, R.A.; Pries, J.H. Constructed wetlands for livestock wastewater management. Ecol. Eng. 2000, 15, 41-55. [CrossRef]

34. Ensign, S.H.; Doyle, M.W. In-channel transient storage and associated nutrient retention: Evidence from experimental manipulations. Limnol. Oceanogr. 2005, 50, 1740-1751. [CrossRef]

35. Schulz, M.; Kozerski, H.P.; Pluntke, T.; Rinke, K. The influence of macrophytes on sedimentation and nutrient retention in the lower river Spree (Germany). Water Res. 2003, 37, 569-578. [CrossRef]

36. Stofleth, J.M.J.; Shields, F.D.; Fox, G.A. Hyporheic and total transient storage in small, sand-bed streams. Hydrol. Process. 2008, 22, 1885-1894. [CrossRef]

37. Harvey, J.W.; Conklin, M.H.; Koelsch, R.S. Predicting changes in hydrologic retention in an evolving semi-arid alluvial stream. Adv. Water Resour. 2003, 26, 939-950. [CrossRef]

38. Triska, F.J.; Jackman, A.P.; Duff, J.H.; Avanzino, R.J. Ammonium sorption to channel and riparian sediments-A transient storage pool for dissolved inorganic nitrogen. Biogeochemistry 1994, 26, 67-83. [CrossRef]

39. Ventura, W.B.; Yoshida, T. Ammonia volatilization from a flooded tropical soil. Plant Soil 1977, 46, 521-531. [CrossRef]

40. Wondzell, S.M. Effect of morphology and discharge on hyporheic exchange flows in two small streams in the Cascade Mountains of Oregon, USA. Hydrol. Process. 2006, 20, 267-278. [CrossRef]

(C) 2018 by the authors. Licensee MDPI, Basel, Switzerland. This article is an open access article distributed under the terms and conditions of the Creative Commons Attribution (CC BY) license (http:/ / creativecommons.org/licenses/by/4.0/). 